\title{
An Investigation of Student Teachers' Anxiety Related to the Teaching Practicum
}

\author{
Dila Charisma \& Puteri Nurmalasari \\ Universitas Muhammadiyah Cirebon, Indonesia \\ (dilla.charisma@umc.ac.id)
}

\begin{abstract}
This study aimed at investigating the student teachers' anxiety related to the teaching practicum as well as the factors that contribute anxiety during teaching practicum, and exploring the student teachers' strategies in overcoming their anxiety during teaching practicum. In order to answer the research problem, qualitative research with a case study approach was employed in this study. STKIP Invada Cirebon was chosen as the site and English student teachers were the participants of this study who did teaching practicum at SMK RISE Kota Cirebon, while the data were collected through interview and weekly journal. This study discovered that student teachers' anxiety related to the teaching is situation-specific anxiety, and the factors which contribute to anxiety can be grouped into six categories: being not familiar with the situations in the classroom, being observed by mentor or supervisor, incompetence in teaching, not meeting expectations, less English proficiency, and classroom management. This study also identified six categories on how to cope with anxiety; adapting, preparing, building a good relationship with the mentor and the students, boosting self-confidence, developing positive thinking, and keeping calmness and excitement. The findings of this study give insight for university supervisor, mentor, and student teachers that anxiety may arise during teaching practicum.
\end{abstract}

Keywords: Student teachers' anxiety; teaching practicum; cause of anxiety, anxiety strategies.

Current English teacher education emphasizes the importance of teaching practicum to improve the quality of English teaching. One of the importance of teaching practicum is give the real experience teaching in the classroom with the real students and student teacher as a teacher. Enginarlar (In
Barahmeh, 2016, p. 16) states the dissatisfaction with the quality of English teaching is generally attributed to teacher education programs at universities, and one of these essential programs is the "practicum", in which finalyear student teachers observe mentor teachers in real classroom and do practice teaching 
to real students, has an enormous impact on improving the quality of teachers and language teaching as a result.

The purposes of the teaching practicum are to allow student teachers experience the practical realities of the school environment, and make use of different teaching techniques and materials to gain experience as many as possible under the supervision of their mentors and university supervisors (Richards \& Crookes in Lestari, 2017, p.1). In other words, the purposes of teaching practicum are to give real experience for the student teachers about school environment, understand teaching and learning process in the classroom under supervision of their mentor and university supervisor, and know the meaning of teacher as a profession. Such objective is important to assure the graduates of education programs are ready to face real classes in the field.

The student teachers find the period of teaching practicum is very demanding and challenging because it represents the range of experience to which student teachers are exposed to when they work in classrooms and schools (Ngidi \& Sibaya, 2018, p. 18; Marais \& Meier, 2004, p. 221). From this statement, during the teaching practicum they are encouraged to behave like a member of the teaching staff by preparing lesson plan before each teaching session and taking part in all school events gathering with mentors. This unusual situation that makes student teachers feel anxious and worries. This feeling causes high level of stress in teaching practicum

Perry (2004, p. 3-4) asserts that teaching practicum can be very exciting and challenging and as a result it creates a mixture of anticipation, anxiety, excitement, and apprehension. She emphasizes further that this excitement can be elaborated in two folds. Firstly, student teachers can be excited of being part of a real classroom setting, getting to know students, planning and organizing classroom tasks. Secondly, student teachers have doubts about their ability to cope with unfamiliar situations such as: controlling and managing learner or establishing a working relationship with field-based and faculty-based supervisor. Based on this statements, teaching practicum can be more exciting and challenging that can cause of anxiety, doubt, apprehension and excitement. Student teachers are required to be part of a real classroom, knowing the students, making goals and coordinating tasks, controlling and managing students in the classroom and working relationship with school and faculty. This unusual situation make the student teachers doubt about their abilities. Those statement above in accordance with Kauffman (in Gürsoy, 2013) that the teaching practice plays a crucial role in preapring student teachers for real classroom teaching.

Ormrod (2011, p. 401) defines that anxiety as "a feeling of uneasiness, nervousness, and apprehension concerning a situation with an uncertain outcome." Anxiety arises when feeling of nervous, unease and fear toward the situation which is not necessary happen. Another definition is explained by Scovel (In Brown, 2007, p. 151) he states that anxiety is associated with feelings of uneasiness, frustration, self-doubt, apprehension or worry. In other words, people who experience uneasiness, frustration, selfdoubt, apprehension or worry it means they are in anxiety. While according to Hartmann (2014, p. 1), "anxiety is a subjective state of apprehension, or tension" which "in the face of naturally fearful or threatening situation; anxiety is a normal and understandable reaction". Therefore, everyone gets anxious at certain times in their lives, because anxiety is a natural feeling of being threatened, apprehension, tension or worry related to the unknown situation.

Feelings of anxiety and stress are also contain in the holy book of the Qur'an. Many people turn a blind and do not understand the existence of the Qur'an which a solution in organize and clean the heart from various heart diseases. For example in the Word of God, as follows: 
"Yes, (on the contrary, whoever submits his face (i.e., self) in Islam to Allah while being a doer of good will have his reward with his Lord. And no fear will there be concerning them, nor will they grieve." (Al-Baqarah: 112).

Several causes of student teachers' anxiety in dealing teaching practicum arose, Aydin and Bahçe (2001) reported classroom management as the most cited source of anxiety ( $43 \%)$; other factors that cause anxiety were the teaching process, relationship with the students, and problem caused by the student teachers' status.

There were many previous studies and the writer took three previous studies to support this article. The first study was conducted by Naltan Lampadan at a faith-based International University, Central Thailand Faculty of Education and Psychology in 2014. This study was intended to fulfill two purposes; to identify the causes of student teachers' anxiety and to discover the coping strategies they employed during internship program. The study discovered that student teachers' anxiety was caused by various factors which can be grouped into three categories; preaparation, classroom management and relationship. This study also identified four categories of coping mechanism employed by student teachers; adaptation, preparation, attitude, and relationship.

Second study was conducted by Mosaddaq \& Barahmeh (2016) which aimed at exploring the different sources of anxiety in which EFL student-teachers experience while doing the practicum courses. The study revealed that EFL student-teachers reflected different sources of anxiety; the main ones were classroom management, time management, lesson planning, being observed and fluency in language.

The last was study delivered by Merç (2011, p. 81). It identified that anxiety was one of the most frequently reported problems of student teachers in completing their teaching practicum at Anadolu University Faculty of Education. The sources of anxiety reported by the student teachers were: being unfamiliar with the classroom situation and classroom management, students' low proficiency, students' disinterest, students' lack of participation that results in failure to the objectives of the lesson, students' disruptiveness, anxiety about student teachers' classroom language, observation and evaluation from the supervisors caused anxiety to the student teachers', anxiety because of the previous experience, anxiety caused by first-day class, anxiety caused by feeling of incompetence in teaching, anxiety caused by being observed and recorded by the cooperating teacher, anxiety due to using the time effectively, anxiety being unfamiliar with students, and anxiety of using a new device.

Based on those sources of anxiety reported in previous studies, this study aimed at investigating what anxiety the student teachers encountered during teaching practicum by looking at the sourses that contribute to the student teachers anxiety as well as the strategies to overcome their anxiety from the student teachers of STKIP Invada Cirebon majoring English education program who did theaching practicum at SMK RISE Kota Cirebon, Indonesia.

\section{Method}

The study employed the qualitative research with case study approach since this study revealed about the social phenomenon that was happening with student teachers during teaching practicum. This is in accordance with Lodico, et al. (2010) that qualitative research is typically focused on the social phenomenon obtained from people's view to acquire a detailed understanding of the issue being studied. This case study allowed the researcher to study particular student teachers 
in an attempt to understand the case of anxiety in teaching practicum. There were two student teachers, both of them are females. They did teaching practicum from July to August 2019.

Obtaining the data, the researcher used two methods of data collection. Student teachers were given interview and weekly journal. The interview was a semi structure interview consist of 10 open-ended questions related to the situation causes them to get anxious, causes of anxiety and strategies employed to cope with teaching practicum anxiety. While the weekly journal was to obtain direct evidence written by student teachers weekly. This weekly journal consist of student teachers' point of views related to events happened in the classroom as well as their feelings during teaching practicum and the factors contributed their anxiety and strategies to overcome it. The weekly journals were set into four. Two journals were for week one and week two which has 7 questions. The other two were for week three with 5 questions and week four with 6 questions. The questions given were related to the point of views of the student teachers.

In the interview, the responses from the participants was translated and described. Some parts of transcrips from interviews were included in the findimgs of the study. While the weekly journal which showed the student teachers' way to overcome anxiety was included to support the findings from interview.

\section{Results and Discussion}

From the interview and weekly journals from the student teachers, It showed what anxiety were the student teachers encountered during the teaching practicum, what factors were contributing the anxiety of student teachers as well as their strategies in overcoming anxiety during the teaching practium. This section was separated into three parts; types of anxiety, factors to contribute anxiety, strategies to overcome anxiety.
Types of Anxiety Encountered by Student Teachers

It could be identified that anxiety the student teachers encounter related to teaching practicum was situation-specific anxiety. Activity of giving speech or giving material in English, and being observed by mentor when teaching in the classroom made student teachers experienced more anxious during the teaching practicum.

\section{Factors to Contribute Student Teachers' Anxiety}

The first factor was being not familiar with the situations in the classroom. The participants responded that they were anxious because being not familiar with the situations and the students in the class. They said that it was very different from micro teaching. In micro teaching they taught their friends / classmate as the students and their lecturer was as a mentor. But in the classroom they found the real students with different characters and different levels of ability which were larger in number compared to micro teaching. This situation made them shocked and nervous, anxious, and fearful.

The second factor was being observed by mentor or supervisor. According to the partcipants information, being observed by mentor was one the reason why the participants feel nervous, anxious, unease, and fearful in teaching. They said that they was feeling embarrassed and nervous when the mentor observed their teaching in the classroom, and they were feeling anxious and worried about the assessment from their mentor, they fear about the negative evaluation by mentor.

The third factor was incompetency in teaching. The result of interview and weekly journal written by student teachers showed that anxious feeling grew in delivering the material, participants was afraid of making mistakes, or not mastering the taught material. In addition, participants were demanded to employ the lesson they have prepared, feeling confused about the appropriate teaching method to be implemented in the 2013 curriculum in order 
to invite students to be more active during the lesson. Participants were not quite competence in teaching due to the lack of experience they have in teaching and also knowlegde related to learning methods.

The fourth factor was that the setting objectives of learning was not met, or in other words, it was not match with the expected result.The student teachers have actually prepared everything before teaching, but when it comes to the teaching time, everything went wrong. The condition was different from the expectation, that what made the lesson plan did not work as it supposed to be. People could have anxiety when the expectation was not met.

The fifth factors was proficiency in English. Both participants said that teaching in English caused feeling of anxiety. Moreover, the mentor told them to be use more English when delivering the material. Student teachers themselves realized that their English competence were still lack, especially in speaking and grammar. They got anxious and worried when they had to deliver the materials using English to their students. Moreover, the mentor was there observing them. This even made the more anxious and worried about their performance during the teaching practicum.

The sixth factor was classroom management. Managing a big class with many students with heterogeneous profiles was a challenge for student teachers during the teaching practicum. They found it hard when finding their students were lack of participation during the class, busy with themshelves, and forgot completing their homework or tasks. These have made them even more anxious.

\section{Strategies to Overcome Anxiety}

The first strategy was adaptation. Both participants recognized that adaptation could overcome and reduce anxiety during the teaching practicum. Accepting the conditions of the class was different from micro teaching, knowing the characters of each student they taught, and implementing the rules that exist in a school were part of the adaptation they had to deal with.

The second strategy was preparation. The result of interview and weekly journal could be concluded that making preparations was the main thing to anticipate anxiety during teaching practicum. For examples, making a lesson plan before going to class, enriching vocabulary, watching learning videos on youtube to apply in the class, and discussing with friends and mentors were some ways to help them minimize their anxiety.

The third strategy was to build good relationship with the mentor and the students. Good relationship with mentor found to be very influential in the development of student teachers' teaching in the classroom. Student teachers needed to communicate with their mentor regarding the problems experienced in the class. The student teachers also needed to have good relationships with students as well. Good cooperation with students was the one strategy to create a conducive learning situation in the classroom.

The fourth strategy was boosting their self confidence. The finding of interview and weekly journal, both of student teachers also showed that self confidence could reduce anxiety during teaching practicum. Believing in own abilities was one of the ways to overcome anxiety related to teaching practicum.

The fifth strategy was to have positive thinking. According to Lampadan (2014), student teachers realized that they could be in an unexpected situation and they needed to stay positive. Therefore to think positively must always be awakened in mind to produce positive results.

The sixth strategy was to keep calm and relax. Both participants said that stayed calm in facing the challenges and difficulties, and stayed relaxed and enjoyed the conditions were effective ways to overcome anxiety during teaching practicum. 


\section{Conclusion}

Numbers of factor have been encountered during the teaching practicum by the student teachers. Those factors included specific situation which was different from the normal situation the student teachers used to face. Moreover, they were being observed or supervised during the teaching practicum. Other factors were also affecting the anxiety even more, such as being unfamiliar with the classroom, including the students' profiles, the classroom management, being lack of teaching experience which affects the performance during the teaching practicum. Overcoming those anxiety factors, some strategies were employed by the student teachers during the teaching practicum such as being selfconfident, having good preparation, building good rapport with the mentor as well as the students, and the most important was to always think positively and enjoy the situations they dealt with.

\section{References}

Aydin, B., \& Bahçe, A. (2001). Cases from student teachers. Paper presented at the International ELT Conference- 2001 on "Searching for Quality in ELT" May 2-4, 2001. Eastern Mediterranean University, Gazimagusa.

Barahmeh, M. Y. (2016). A Study of Sources of EFL Student Teachers' Anxiety During Their Practicum Experience. European Journal of Research and Reflection in Educational Sciences, 4(1), 16-25.

Brown, H. Douglas. (2007). Principles of Language Learning and Teaching. New York: Pearson Education.

Gürsoy, E. (2013). Improving practicum for a better teacher training. Procedia-Social and Behavioral Sciences, 93, 420-425.

Hartmann, P. M. (2014). Anxiety. Magill's Medical Guide (Online Edition),http:// libproxy.lamar.edu/login?url=http:// serach.ebscohost.com/login.aspx?direct
[2019, April 02]

Lampadan, N. (2014). Understanding the Causes of Anxiety and Coping Strategies of Student-Teachers during Their Internship: A Phenomenological Study. Institute Press, 10(2), 34-45.

Lestari, H. (2017). Exploring Student Teachers' Anxiety Related to the Teaching Practicum. Unpublished research thesis, Universitas Pendidikan Indonesia, Bandung.

Lodico, V., Mahboob, A., \& Liu, M. (2010). A comparison of three methods for the collection of L2 data: Free composition, translation, and picture description. Working Paper on Bilingualism, 8, 593598.

Marais, P. \& Meier, C. (2004). Hear Our Voices: Student Teachers' Experiences during Practical Teaching. Africa Education Review, 1. 220-223.

Merç, A. (2011). Sources of Foreign Language Student Teacher Anxiety: A Qualitative Inquiry. Turkish Online Journal of Qualitative Inquiry, 2(4). 87-90.

Mosaddaq \& Barahmeh, Y. (2016). A Study of Sources of EFL Student Teachers' Anxiety during their Practicum Practice. European Journal of Research and Reflection in Educational Science, 4(1). 16-25.

Ngidi, D. P., \& Sibaya, P. T. (2003). Student teacher anxieties related to practice teaching. South African Journal of Education, 23(1), 18-22.

Ormrod, J. E. (2011). Educational Psychology: Developing Learners. Boston: Pearson/ Allyn \& Bacon.

Perry, R. (2004). Teaching practice for early childhood: A guide for students. Retrieved from http://www.routledge.com/ catalogues./0418114838.pdf. [2019, March 11] 